This manuscript was published in

Masscheleyn P.H., Tack F.M., Verloo M.G., 1996. Feasibility of a counter-current extraction procedure for the removal of heavy metals from contaminated soils. Water, Air, and Soil Pollution $89,317-335$.

The original publication is available at http://www.springerlink.com/openurl.asp?genre=article\&id=doi:10.1007/BF00171639

\title{
FEASIBILITY OF A COUNTER-CURRENT EXTRACTION PROCEDURE FOR THE REMOVAL OF HEAVY METALS FROM CONTAMINATED SOILS
}

\author{
P.H. MASSCHELEYN, F.M. TACK* and M.G. VERLOO \\ Laboratory of Analytical Chemistry and Applied Ecochemistry, University of Ghent, Coupure Links \\ 653, B-9000 Gent, Belgium \\ ( ${ }^{*}$ Corresponding author)
}

\begin{abstract}
Effective remediation and sanitation technologies for soils contaminated with heavy metal are limited. We investigated the feasibility of a counter-current metal extraction procedure for the removal of selected heavy metals $(\mathrm{Cd}, \mathrm{Cu}, \mathrm{Pb}$, and $\mathrm{Zn})$ from two contaminated soils. The process involved a decarbonation (removal of carbonates), acid solubilisation, washing, and liming step. Results from batch equilibration experiments simulating the counter-current process showed more than $85 \%$ of the $\mathrm{Cd}$ present to be removed. Removal efficiencies for $\mathrm{Cu}$ and $\mathrm{Pb}$ were limited to approximately $15 \%$, this mainly due to resorption of these elements during the decarbonation step. As most $\mathrm{Zn}$ was found to be present in a more difficult acid-extractable solid phase, its extractability accounted for only $25 \%$. While reaction $(\mathrm{pH})$ conditions of both decarbonation and solubilisation determined removal efficiencies, washing the extracted soil with deionized water only slightly increased the amount of metals removed. Metal distribution among solid phases exchangeable, carbonate, reducible, organically bound, and residual - was affected by the different treatments. The amount of metals contained in the exchangeable and residual fractions determined their extractability. Except for $\mathrm{Cu}$, the reducible and organically bound fractions were less important. After solubilisation 13 to $70 \%$ of the metals were present in an exchangeable solid phase. This implicates that washing the solubilized soil with a salt may increase the extractability of metals, especially for $\mathrm{Zn}$ and $\mathrm{Pb}$. Based on our results the process is critically evaluated and possibilities for optimization formulated.
\end{abstract}

Keywords: soil remediation; extraction; heavy metals

\section{Introduction}

There is a lack of strategies for dealing with heavy metal contaminated soils (Daley, 1989; Sims, 1990; Sheppard and Thibault, 1992). Excavation of metal polluted soils to landfills is common practice in many European countries but the costs involved and the ever decreasing amount of acreage available for dumping has intensified the search for efficient, cost effective treatment methods for metal-polluted soils. Present technologies include chemical stabilization, physical separation and extraction techniques (Assink, 1988; Daley, 1989; Esposito et al., 1989). Conventional stabilization techniques involve $\mathrm{pH}$ increase and/or immobilization through addition of lime or alumo-silicates (DeBoodt, 1991; Powell and Mahalingan, 1992; Mench et al., 1994). By means of hydro-cyclones, contaminated fines can be separated from coarse soil material, thereby 
effectively reducing the volume of the contaminated portion of the soils (Esposito et al., 1989). Extractive techniques, such as acid extractions and extractions with metal complexing agents, transfer the metals from the solid soil phase to the extractant (Brümmer et al., 1991; Tuin and Tels, 1991; Allen and Chen, 1993). The extract can be further treated to recover metals. Although the efficacy of some of these techniques still needs to be proven they are currently being used in the restoration and sanitation of soils contaminated with heavy metals.

As part of a comprehensive investigation on sanitation techniques for metal contaminated soils, we designed a counter-current acid extraction procedure (Figure 1) and studied the behavior of selected heavy metals $(\mathrm{Cd}, \mathrm{Cu}, \mathrm{Pb}$, and $\mathrm{Zn})$ during this procedure. Soil metals are extracted in a three-step process including decarbonation (removal of carbonates), solubilisation, and washing. Metal solubilisation occurs at a $\mathrm{pH}$ of 1 . The acid extract is then used to pretreat (decarbonate) the contaminated soil in the first step of the counter-current extraction procedure. The soil leaving the solubilisation step undergoes a final washing step. Then, the soil is limed. This remediation process could be executed on-site and makes optimal use of the acid added. Both facts should make the procedure cost effective.

It was hypothesized that the metal extraction strategy put forward in Figure 1 would result in a decontaminated soil, low in total metal content. This study reports on the feasibility and efficiency of soil metal extraction by the counter-current acid extraction procedure. The flow of metals in the several steps of the procedure is determined. On the basis of a selective extraction procedure, metal partitioning among several conceptually defined solid phase fractions during the counter-current extraction procedure is described. Advantages/shortcomings of the process are illustrated and suggestions for increasing the metal extraction efficiency and process optimization listed.

\section{Materials and methods}

\subsection{SOIL SELECTION AND CHARACTERISATION}

Surface soils were collected at Tielrode and Kruibeke (Belgium), located in the neighborhood of the city of Antwerp. The sites are now agricultural fields but have been flooded by the Sheldt river in the past and are therefore contaminated with metals.

Granulometric analysis was used to determine soil texture. Chemical properties ( $\mathrm{pH}$, cation exchange capacity, $\mathrm{C}$ content, Kjeldahl $\mathrm{N}$, and carbonate content) were determined using standard procedures as described in Cottenie et al. (1982). Total metal ( $\mathrm{Cd}, \mathrm{Cu}, \mathrm{Pb}$, and $\mathrm{Zn})$ contents were measured after aqua regia extraction (Ure, 1990). Flame and graphite furnace atomic absorption spectroscopy were used to quantify the amount of metals in solution.

\subsection{Titration CURVE AND METAl SOLUBiLisATION EDGE}

To determine soil titration curves, increasing amounts of $2 \mathrm{M} \mathrm{HCl}$ were added to suspensions of $10 \mathrm{~g}$ soil in distilled water. The volume of distilled water was measured to obtain a soil:liquid ratio of 1:5 after addition of the acid. Acidified suspensions were equilibrated for $60 \mathrm{~min}$ on a reciprocating shaker and filtered. The $\mathrm{pH}$-values of the filtrates were determined and the concentration of $\mathrm{Cd}, \mathrm{Cu}, \mathrm{Pb}$, and $\mathrm{Zn}$ in the extracts measured. The experiment was carried out in triplicate. 


\subsection{Metal extraction scheme}

To simulate the flow of metals during a counter-current soil-acid extraction procedure (Figure 1) a series of batch equilibrations and extractions were conducted. In a first series of experiments each step in the counter-current extraction procedure (decarbonation, solubilisation, washing, and liming) was studied independently. Soil suspensions with a final soil:liquid ratio of 1:5 were prepared by mixing soil equivalent to $150 \mathrm{~g}$ dry soil with deionized water, acid, or acid extract, and continuously stirred in $1 \mathrm{~L}$ pyrex beakers for $1 \mathrm{hr}$. Controlled $\mathrm{pH}$ conditions were obtained by addition of known volumes of $2 \mathrm{M} \mathrm{HCl}$ using an automatic $\mathrm{pH}$ stat/titrimeter. After equilibration, soil suspensions were filtered by using a vacuum-filter system. An aliquot of the extract and a representative sample of the extracted soil were kept for analysis. If needed, the rest of the extracted soil or extract were used in a following step. All equilibrations and extractions were carried out in triplicate. The following batch equilibrations and extractions were performed:

(1) acidification and equilibration of contaminated soil at $\mathrm{pH}=4$.

(2) acidification and equilibration of contaminated soil at $\mathrm{pH}=1$.

(3) equilibration of $\mathrm{pH} 1$ acidified soil from (2) with deionized water.

(4) equilibration of contaminated soil with the acid extract obtained in (2).

(5) equilibration of $\mathrm{pH} 4$ acidified soil from (1) with the wash water from (3) and further acidification to $\mathrm{pH} 1$.

(6) liming of soil from (3).

The developed batch extraction scheme allows for the evaluation of the different steps present in the counter current soil-acid extraction process depicted in Figure 1. While equilibration (4) represents Step 1 (DECARBONATION) in Figure 1, extractions (5) and (3) approximate Step 2 (SOLUBILISATION) and Step 3 (WASHING), respectively. Equilibration (6) represents the liming of the "decontaminated" soil.

For each equilibration and extraction step we determined the dry weight and the $\mathrm{Cd}, \mathrm{Cu}, \mathrm{Pb}$, and $\mathrm{Zn}$ content of the soil before extraction. We also measured the volume and metal content of extractant and extract. Using this information, mass balances for the metals of interest were computed to evaluate the behaviour and flow of $\mathrm{Cd}, \mathrm{Cu}, \mathrm{Pb}$, and $\mathrm{Zn}$ during the counter-current extraction scheme.

\subsection{SOLID PHASE FRACTIONATIONS}

A selective metal extraction procedure was devised to separate operationally exchangeable, carbonate, reducible, organic, and residual solid phase fractions from soils. Metals present in the "exchangeable" phase were extracted using potassium nitrate ( $\mathrm{pH} 7)$ according to Emmerich et al. (1982). Metals precipitated as -or with- carbonates were solubilized with sodium acetate at pH 5 (Tessier et al., 1979). Trace metals associated with reducible amorphous Fe and Al oxides were determined after acid ammonium oxalate (McKeague and Day, 1966) extraction. As these three single extraction steps represent increasingly stronger extraction agents, we subtracted the exchangeable metal content from the sodium acetate extractable metal content in order to obtain the amount of metals present as "bound to carbonates". The amount of metals present in the reducible fraction was calculated as follows: ammonium oxalate extractable - (exchangeable + carbonate bound). Although it is recognized that the extractions are not always as selective as sometimes stated (Kheboian and Bauer, 1987; Greubel et al., 1988) the selective extraction procedure was used to provide information on metal distribution among solid phase fractions. Organically bound metals were determined after extraction with a $0.2 \mathrm{M}$ sodium hydroxide solution (Cottenie et al., 1982). The residual metal fraction represents the difference between total metal content and the sum of 
metals present in the four fractions.

The series of selective extractions was used to follow the solid phase metal behavior during the different extraction steps described above and to formulate possible improvements to the counter-current extraction procedure (Figure 1).

\subsection{COUNTER-CURRENT METAL EXTRACTION}

In a second experiment, the different steps in the proposed counter-current extraction scheme (Figure 1) were consecutively executed. We used an array of batch equilibrations to simulate the counter-current procedure. The approach taken was basically the same as in the experiments above, although the execution differed and became more complicated. As above, a 1 to 5 soil:extractant ratio, an equilibration time of $1 \mathrm{hr}$ and $2 \mathrm{M} \mathrm{HCl}$ were used. Equilibrations were performed in centrifuge tubes using $20 \mathrm{~g}$ dry soil on a reciprocating shaker. Based on information on soil acid buffer capacity, an amount of $\mathrm{HCl}$ was added to achieve the desired $\mathrm{pH}$. In contrast to experiment 1 the $\mathrm{pH}$ was not controlled or kept constant during the equilibration. After equilibration, centrifugation (15 min at $2500 \mathrm{rpm}$ ) was used to separate the solid phase (extracted soil) and extract.

In a first step, contaminated soil (X1) was acidified and equilibrated at $\mathrm{pH}=4$ (DECARBONATION Step in Figure 1). After equilibration and centrifugation, the extract was decanted, and filtered. Soil (X1) remained in the centrifuge tube and was acidified to $\mathrm{pH}=1$ (SOLUBILISATION step in Figure 1), taking care that the final soil/liquid ratio was $1 / 5$. After equilibration (solubilisation) at $\mathrm{pH}=1$, the phase separation was repeated. The extracted (solubilised) soil (X1) in the tube was subsequently equilibrated with deionized water (WASHING STEP in Figure 1). The acidic extract obtained during the solubilisation step of soil (X1) was equilibrated with another $20 \mathrm{~g}$ of contaminated dry soil (soil (X2) - DECARBONATION), and the phase separation repeated. Then, the "wash water" from soil (X1) (obtained after equilibration of solubilized soil (X1) with deionized water) was added to decarbonated soil (X2), and the suspension further acidified and equilibrated at $\mathrm{pH}=1$ (soil (X2) - SOLUBILIZED). The phase separation was repeated. The solubilized soil (X2) was equilibrated with deionized water (soil (X2) - WASHED) and solid and liquid phases separated. Liquid phases obtained in the extractions of soil (X2) were then used to treat the next $20 \mathrm{~g}$ of contaminated dry soil (soil (X3)).

In the above extraction procedure each $20 \mathrm{~g}$ of contaminated soil undergoes consecutively a decarbonation, solubilisation, and a washing step. The liquid phases obtained in the extractions are used as input (extractant) in the subsequent step of the process. In this manner the counter-current extraction scheme could be simulated. In order to reach quasi steady state conditions the procedure was repeated seven times.

\section{Results and discussion}

\subsection{SoIl CHARACTERISTICS, TITRATION CURVES, AND METAL SOLUBILISATION EDGES}

The mineralogy, selected chemical properties, and total metal content of the soils used in our study are listed in Table I. Both soils had a clayey loam texture. The soil from Tielrode had a higher $\mathrm{CaCO}_{3}$ content and lower cation exchange capacity than the soil from Kruibeke. Both soils were contaminated with $\mathrm{Cd}$ and $\mathrm{Pb}$. The soil from Tielrode also contained elevated levels of $\mathrm{Zn}$ and to a lesser extent of $\mathrm{Cu}$. Soil $\mathrm{Cd}, \mathrm{Pb}$ and $\mathrm{Zn}$ contents were higher than the "warning level" concentration $\left(5,150\right.$, and $500 \mathrm{mg} \mathrm{kg}^{-1}$ dry soil for $\mathrm{Cd}, \mathrm{Pb}$, and $\mathrm{Zn}$, respectively) as put forward by the Dutch Ministry of Housing, Physical Planning and Environment (Van den Brink, 1985). 
By acidification of soils, $\mathrm{H}^{+}$buffering phases are either consumed or lose their ability to consume $\mathrm{H}^{+}$. Calcium carbonate content and cation exchange capacity are reported to be the most important soil characteristics neutralizing the rapid addition of $\mathrm{H}^{+}$(Van Breemen et al., 1984). Due to its higher $\mathrm{CaCO}_{3}$ content the soil from Tielrode was better buffered with respect to $\mathrm{pH}$ changes (Figure 2) and released less of the metals upon initial acidification (Figure 3A versus 3B).

Carbonate content of the soils governed the acidity and also the metal concentrations in solution. It, therefore, will be an important factor influencing the metal extracting efficiency in a sanitation procedure that involves acid extraction.

Within the $\mathrm{pH}$ range of 7 to 1.5 the solubilisation of metals for both soils with decreasing $\mathrm{pH}$ was as follows: $\mathrm{Cd}>\mathrm{Zn}>\mathrm{Pb}=\mathrm{Cu}$. At lower $\mathrm{pH}$ values metal solubilisation followed the trend: $\mathrm{Cd}>\mathrm{Pb}>\mathrm{Cu}>\mathrm{Zn}$. In order to release $50 \%$ of the total $\mathrm{Cd}, \mathrm{Pb}$, and $\mathrm{Zn}$ from the Kruibeke soil acidification to $\mathrm{pH}$ values of respectively $2.3,0.7$ and 0.65 were necessary. For the soil from Tielrode $50 \%$ of the total $\mathrm{Cd}, \mathrm{Cu}$, and $\mathrm{Pb}$ were solubilized at a $\mathrm{pH}$ of approximately $4.2,0.9$, and 1.2 respectively. As the soil buffer capacity was exhausted and the $\mathrm{pH}$ dropped below 1, 85 to $97 \%$ of the $\mathrm{Cd}$ and $\mathrm{Pb}$ present in the soils became mobilized. Extractability of $\mathrm{Cu}$ and $\mathrm{Zn}$ remained limited to approximately 65 and $45 \%$ of the total amount present.

Examination of Figures 2 and 3 reveals that a large amount of acid will be required to solubilize major parts of the metals present in the contaminated soils. We postulated that metal extracting efficacy could be improved by subjecting the contaminated soils to more than one acid leaching step. Conducting the extractions in a counter-current manner would make optimal use of the acid added. Based on results depicted in Figures 2 and 3 we decided to conduct the countercurrent extraction at a solubilisation $\mathrm{pH}$ equal to 1 . This would allow to determine the beneficial effects of the procedure (Figure 1) and at the same time limit the amount of acid required.

\subsection{Metal Flow in the DeCarbonation, SOlubilisation, WAShing and Liming STEP OF THE COUNTER-CuRRent METAL EXTRACTION SCHEME.}

The flow of metals in the different steps of the counter-current extraction scheme for the soil from Kruibeke and Tielrode is summarized in Tables II and III, respectively. The metal content of the treated (extracted) soil in these tables was calculated based on the total metal content of the soil before treatment and knowledge of volume and metal concentration of extractant and extract liquid phases. Liquid-solid phase separations by vacuum filtration resulted in a solid phase containing approximately $70 \%$ dry matter. The other $30 \%$ represented residual metal laden extract. As these metals remained in the treated soil we did not correct soil metal content for metals present in the interstitial acidic solution. Calculations showed this amount to account for less than $10 \%$ of the total amount of metals present in the soil.

Equilibrations 1 and 2 in Tables II and III represent acidification of the contaminated soils to $\mathrm{pH} 4$ and $\mathrm{pH}$ 1. Extraction 3 involved the equilibration of contaminated soil after extraction at $\mathrm{pH} 1$ with deionized water (Washing step in Figure 1). Upon acidification of the Kruibeke soil to $\mathrm{pH}$ 1, $98,45,51$, and $27 \%$ of the total $\mathrm{Cd}, \mathrm{Cu}, \mathrm{Pb}$, and $\mathrm{Zn}$ content were solubilized (Table II). Washing the acidified soil will remove $5 \%$ of the $\mathrm{Cu}, \mathrm{Pb}, \mathrm{Zn}$, and $33 \%$ of the $\mathrm{Cd}$ remaining in the soil after solubilisation. Soil residues and/or acid extracts from equilibrations 1 to 3 were then used in the equilibration and extraction steps 4 to 6 . Extraction step 4 describes the metal flow during the decarbonation step in the counter-current extraction scheme (Figure 1). When contaminated soil from Kruibeke $(\mathrm{pH}=6.53)$ was leached with the acid extract $\mathrm{pH}$ 1, the suspension $\mathrm{pH}$ dropped to 1.52 (Table II, equilibration 4). Although the leaching extract was contaminated with $\mathrm{Cd}, \mathrm{Cu}, \mathrm{Pb}$, and $\mathrm{Zn}$, part of the metals from the contaminated soil was solubilized during the equilibration. The higher metal content in the obtained effluent as compared to the extractant (extract $\mathrm{pH} 1$ ) illustrates this. The calculated mass balance shows a removal of $92 \% \mathrm{Cd}, 12 \% \mathrm{Cu}, 10 \% \mathrm{~Pb}$, and $21 \% \mathrm{Zn}$ of 
the total amounts present in the contaminated soil during the decarbonation step. In the countercurrent extraction procedure, soil metal content will further decrease during the solubilisation step. This can be deducted from extraction step 5 (Table II). The addition of metal containing wash water to the soil acidified to $\mathrm{pH} 4$ and subsequent acidification of the suspension to $\mathrm{pH} 1$ lead to a soil containing 1.4, 25, 98, and $167 \mathrm{mg} \mathrm{kg}^{-1}$ dry soil of $\mathrm{Cd}, \mathrm{Cu}, \mathrm{Pb}$, and $\mathrm{Zn}$, respectively. After the soil was limed, water soluble $\mathrm{Cu}$ and $\mathrm{Zn}$ concentrations were low and $\mathrm{Cd}$ and $\mathrm{Pb}$ levels undetectable.

Metal flow and extracting efficiencies obtained during the experiments with the soil from Tielrode (Table III) differed from the ones obtained with the Kruibeke soil (Table II). Metal extraction at $\mathrm{pH} 1$ removed $85,54,53$, and $24 \%$ of the total soil $\mathrm{Cd}, \mathrm{Cu}, \mathrm{Pb}$, and $\mathrm{Zn}$ content. An extra $35 \% \mathrm{Cd}, 8 \% \mathrm{Cu}, 3 \% \mathrm{~Pb}$, and $6 \%$ of $\mathrm{Zn}$ remaining in the soil after solubilisation were removed from the solubilized soil after washing. Difficulties with respect to metal removal arose during the decarbonation step (Table III - equilibration 4). When the contaminated soil $(\mathrm{pH}=7.43$ ) was equilibrated with the acid $\mathrm{pH} 1$ extract, the $\mathrm{pH}$ initially dropped to 3.5 but increased gradually during the equilibration to reach a final suspension $\mathrm{pH}$ of 5.22. As a result, metal mobilization was low. The observed $\mathrm{pH}$ increase during equilibration 3 was accompanied by gas $\left(\mathrm{CO}_{2}\right)$ evolution illustrating the decarbonation taking place. In addition to the low extraction efficiency, we also observed resorption of $\mathrm{Cu}, \mathrm{Pb}$, and $\mathrm{Zn}$ present in the $\mathrm{pH} 1$ extractant solution, to occur. Trace metals released during the dissolution step were sorbed on the contaminated soil during the decarbonation step. This lead to increased soil $\mathrm{Cu}, \mathrm{Pb}$, and $\mathrm{Zn}$ contents. Thirty five $\%$ of the total soil $\mathrm{Cd}$ became soluble during the decarbonation step. Acidification to $\mathrm{pH} 1$ of the soil $\mathrm{pH} 4$ in wash water (equilibration 5) resulted in a mobilization of $85,60,66$, and $25 \%$ of the soil total $\mathrm{Cd}, \mathrm{Cu}, \mathrm{Pb}$, and $\mathrm{Zn}$ content. Although the solubilization step removed a major part of the metals from the contaminated soil one should keep in mind that the soil entering the solubilisation step in the counter-current extraction procedure will have become enriched in $\mathrm{Cu}, \mathrm{Pb}$, and $\mathrm{Zn}$ during the decarbonation step. After the soil was limed with $\mathrm{Ca}(\mathrm{OH})_{2}$, extractable metals were low (Table III equilibration 6).

\subsection{Solid phase fractionation of $\mathrm{C}$, $\mathrm{Cu}, \mathrm{P}_{\mathrm{B}}$, and $\mathrm{Z}_{\mathrm{N}}$ during the decarbonation, solubilisation, WASHING AND LIMING STEP OF THE COUNTER-CURRENT EXTRACTION PROCEDURE.}

As metals in soils can exist in a variety of forms, one can expect them to exert different reactivities toward acidification. On the basis of solid-phase selective extractions, we investigated the distribution of $\mathrm{Cd}, \mathrm{Cu}, \mathrm{Pb}$, and $\mathrm{Zn}$ in the chemical phases present in the soil as affected by the different reaction steps in the counter-current extraction scheme (Figure 4 and 5). The metal distribution among solid phases was very similar in both soils. In the native soils, Cd was mainly associated with carbonates while the major part of the total $\mathrm{Pb}$ and $\mathrm{Zn}$ content were held within the fraction termed residual. Thus, soil $\mathrm{Pb}$ and $\mathrm{Zn}$ were present in more difficult acid-extractable forms. Except for $\mathrm{Cu}$, the organically-bound fraction of metals was relatively small. The tendency of $\mathrm{Cu}$ to form soil organically-bound complexes will make acid extraction less efficient. The highest percentage of $\mathrm{Cu}$ was present in the reducible amorphous $\mathrm{Al}$ and $\mathrm{Fe}$ fraction.

The percentage of the total metal content extracted in exchangeable forms increased during the decarbonation and solubilisation steps (Figure 4 and 5 - treatments 2 and 3 versus treatment 1). Metals associated with the carbonate fraction were solubilized upon acidification of the soils. Whereas the washing step had no effect on metal distribution, liming the soil caused a significant decrease in exchangeable metals. Data obtained in Figures 4 and 5 allow for some conclusions to be made with regard to increasing the metal extracting efficacy of the procedure. As soil reducible amorphous oxide and organic phases are less important, one can expect that the addition of a reducing or oxidizing step in the procedure will not increase metal extraction. On the other hand washing the solubilized soil with a salt (e.g. $\mathrm{CaCl}_{2}, \mathrm{KNO}_{3}$ ) should remove the amount of metals 
present in the exchangeable phase, and thereby increase the extracting efficiency by $70,13,51$, and $51 \%$ for $\mathrm{Cd}, \mathrm{Cu}, \mathrm{Pb}$, and $\mathrm{Zn}$, respectively, in the Kruibeke soil. For the Tielrode soil an increase in metal extraction efficiency of $43,16,48$, and $60 \%$ can be expected for $\mathrm{Cu}, \mathrm{Zn}, \mathrm{Pb}$, and $\mathrm{Cd}$.

\subsection{FEASIBILITY OF THE COUNTER-CURRENT EXTRACTION SCHEME}

To evaluate the influence of possible metal accumulation in the decarbonation step (Table III equilibration 4) on the overall performance of the procedure and to validate/reject the findings obtained during the first series of experiments, the entire counter-current metal extraction procedure (Figure 1) was simulated in an array of batch equilibrations, as described in the materials and methods section. Computed mass balances for $\mathrm{Cd}, \mathrm{Cu}, \mathrm{Pb}$, and $\mathrm{Zn}$ during the counter-current extraction are given in Figures 6 and 7. Metal flow and mass balances were calculated using data on total metal content in the contaminated soil and amounts of metals removed during the different steps involved.

Metal removal from the contaminated soil from Kruibeke after counter-current extraction (Figure 6) was far less efficient than we expected on the basis of the results from Table II. The main reason for this discrepancy can be related to the behavior of $\mathrm{Cu}, \mathrm{Pb}$ and $\mathrm{Zn}$ during the decarbonation step. During the decarbonation step in the counter-current extraction procedure (Figure 6) the $\mathrm{pH}$ of the contaminated soil decreased to 2.11 . This in contrast to the $\mathrm{pH} 1.52$ obtained in the equilibration experiments (Table II). This difference in $\mathrm{pH}$ condition was responsible for the observed difference in metal solubility. In contrast to our previous observations $\mathrm{Cu}$ and $\mathrm{Pb}$ released in the solubilisation extract were resorbed upon contact with contaminated soil. Subsequent acidification at $\mathrm{pH} 1 \mathrm{did}$ not solubilize enough $\mathrm{Cu}, \mathrm{Pb}$, and $\mathrm{Zn}$ to account for the increase in metal content during the decarbonation step. Mass balances depicted in Figure 6 clearly illustrate the importance of the $\mathrm{pH}$ in the decarbonation step. Metals should be kept in solution during this step. As in the first series of experiments, washing the solubilized soil with water did not increase the removal of metals in a major way. The amount of $\mathrm{Cd}$ extracted during the counter-current metal extraction procedure accounted for $84 \%$ of the total soil $\mathrm{Cd}$. Removal percentages of other metals were limited, mainly due to resorption of the solubilized metals on contaminated soil entering the decarbonation step.

Results obtained during the counter-current metal extraction procedure with the soil from Tielrode (Figure 7) confirmed previous findings. As before (Table III), $\mathrm{Cu}, \mathrm{Pb}$ and $\mathrm{Zn}$ resorbed to the contaminated soil during the decarbonation step. This limited the amount of extracted $\mathrm{Cu}, \mathrm{Pb}$, and $\mathrm{Zn}$ to respectively $10,10.5$, and $13.5 \%$ of the total soil content. Ninety seven $\%$ of the total soil $\mathrm{Cd}$ was removed during the extraction procedure. Again, the contribution of the washing step to the total efficiency of the procedure was minimal.

Although the amount of metals extracted from the contaminated soils with the countercurrent extraction technique was rather low, one should keep in mind that in using a counter-current procedure the amount of acid consumed in the process is minimized. Figures 2 and 3 allow for some conclusions to be made regarding the efficiency of a co-current metal extraction scheme that would consume an equal amount of acid equivalents. Equilibrating the soils with an amount of acid equal to that used in the counter-current procedure (Figure 6 and 7) would lead to a soil $\mathrm{pH}$ of 1.65 and 3.31 for the Kruibeke and Tielrode soil, respectively. At this $\mathrm{pH}, 76,9,10$, and $29 \%$ of the total $\mathrm{Cd}$, $\mathrm{Cu}, \mathrm{Pb}$, and $\mathrm{Zn}$ would be removed from the Kruibeke soil. Metal extracting efficiencies for the Tielrode soil would be $64,4,2$, and $18 \%$ for $\mathrm{Cd}, \mathrm{Cu}, \mathrm{Pb}$, and $\mathrm{Zn}$. Comparing these results with the ones obtained in the counter-current extraction procedure shows that, except for $\mathrm{Zn}$, more metals were removed in the latter procedure. As was illustrated above, resorption of solubilized metals during the decarbonation step limited the overall performance of the counter-current method.

In summary, several questions remain concerning the feasibility of the counter-current extraction procedure for removal of heavy metals from contaminated soils. There is obviously a need to closely control and/or optimize the extracting $(\mathrm{pH})$ conditions in the different steps as metal 
extractability will depend on reaction $(\mathrm{pH})$ conditions in both the decarbonation and solubilisation step. Furthermore, metal distribution among several conceptually defined solid phases was affected by the treatments in the extracting process. The interpretation of the obtained results allows for further process optimization. Reacting conditions in the decarbonation step should be made more acidic in order to prevent resorption of metals. Washing the solubilized soil with a solution containing a salt rather than with water would increase the extracting efficacy of the counter-current procedure. In order to further increase metal extractability the procedure (Figure 1) may need some adaptations. In Figure 1, metal solubilisation is obtained in a single extraction at $\mathrm{pH}$ 1. Extracting conditions of the solubilisation step could be made more acidic, which would increase metal extracting efficiency. This would not only mobilize more metals but may also lower the $\mathrm{pH}$ during the decarbonation step at values low enough to prevent metal resorption. Another approach would be to insert a second solubilisation step between the acid extraction $\mathrm{pH} 1$ and the washing step. These options are currently being investigated taking into account both increased extracting efficiency and increased acid requirements.

\section{Acknowledgements}

This research was funded by grant $n^{\circ}$ VLIM/H/9012 from the Flemish Environmental Technology Research Program (Vlaams Impulsprogramma Milieutechnologie).

\section{References}

Allen, H.E., Chen, P.H., 1993: Environmental Progress, 12, 284.

Assink, J.W.: 1988, in Wolf, K. et al. (eds.) Contaminated Soil, Kluwer Academic Publ., Dordrecht, The Netherlands, p. 861.

Brümmer, G.W., Hornburg,V., Hiller, D.A.: 1991, Mitteilungen der Deutschen Bodenkundlichen Gesellschaft, 63, 31.

Cottenie, A., Verloo. M., Kiekens, L., Velghe, G. and Camerlinck, R.: 1982, Chemical analysis of plants and soils, Laboratory for Analytical Chemistry and Agrochemistry, State University of Ghent, 63 pp.

Daley, S.: 1989, Environ. Sci. Technol. 23, 912.

DeBoodt, M. F.: 1991. In Bolt G.H., DeBoodt M.F., Hayes M.H and M.B. McBride (eds.), Interactions at the Soil Colloid - Soil Solution Interface, NATO ASI Series, Series E: Applied Sciences - Vol 190.

Emmerich, W.E., Lund, L.J., Page, A.L. and Chang, A.C.: 1982, J. Environ. Qual. 11, 178.

Esposito, P., Hessling, J., Locke, B.B., Taylor, M., Szabo, M., Thurnau, R., Rogers, C., Traver, R. and Barth, E.: 1989, J. Air and Waste Manag. Assoc. 39, 294.

Gruebel, K.A., Davis, J.A. and Leckie, J.O.: 1988, Soil Sci. Soc. Am. J. 52, 390.

Kheboian, C. and Bauer, C.F.: 1987, Anal. Chem. 59, 1417.

McKeague, J.A. and Day, J.H.: 1966, Can. J. Soil Sci. 46, 13.

Mench, M.J., Didier, V.L, Löffler, M., Gomez, A. and Masson, P.: 1994, J. Environ. Qual., 23, 58.

Powell, M.R. and Mahalingam, R.: 1992, Environ. Sci. Technol. 26, 507.

Sheppard, M.I and Thibault, D.H.: 1992, Soil Sci. Soc. Am. J. 56, 415.

Sims, R.C.: 1990, J. Air Waste Manag. Assoc. 40, 704.

Tessier, A., Campbell, P.G. and Bisson, M.: 1979, Anal. Chem. 51, 844.

Tuin, B.J.W., Tels, N., 1991: Environ. Technol. 12, 178

Ure, A.M.: 1990. In: Alloway, B.J. (ed.), Heavy metals in soils, Blackie and Son, Glasgow, p. 40.

Van Breemen, N., Driscoll, C.T., and Mulder, J.: 1984, Nature, 307, 599.

Van den Brink, W.J.: 1985, Bodemverontreiniging, Uitgeverij Het Spectrum, Utrecht/Antwerpen, $142 \mathrm{pp}$. 


\section{Tables}

TABLE I: Selected mineral and chemical properties of the Kruibeke and Tielrode soil.

\begin{tabular}{lll}
\hline & \multicolumn{1}{c}{ Kruibeke } & Tielrode \\
\hline Clay $(0-2 \mu \mathrm{m})(\%)$ & 32.2 & 23.4 \\
Silt $(2-50 \mu \mathrm{m})(\%)$ & 38.6 & 39.2 \\
Sand $(>50 \mu \mathrm{m})(\%)$ & 29.2 & 37.4 \\
Organic carbon $(\%)$ & 2.42 & 2.00 \\
Carbonate content $(\%)$ & 1.85 & 4.87 \\
Cation exchange Capacity $\left(\mathrm{cmol} \mathrm{H}^{+} / \mathrm{kg}\right)$ & 30.5 & 19.5 \\
$\mathrm{pH}$ & 6.53 & 7.43 \\
\hline $\mathrm{Cd}(\mathrm{mg} / \mathrm{kg})$ & $12.4 \pm 0.23$ & $8.65 \pm 0.3$ \\
$\mathrm{Cu}(\mathrm{mg} / \mathrm{kg})$ & $45.7 \pm 0.4$ & $105 \pm 1.8$ \\
$\mathrm{~Pb}(\mathrm{mg} / \mathrm{kg})$ & $260 \pm 22^{\mathrm{a}}$ & $236 \pm 6.0$ \\
$\mathrm{Zn}(\mathrm{mg} / \mathrm{kg})$ & $262 \pm 16$ & $1516 \pm 199$ \\
\hline
\end{tabular}

a: mean and standard deviation of 4 replicate determinations 
TABLE II: Metal flow during batch equilibrations with the Kruibeke soil.

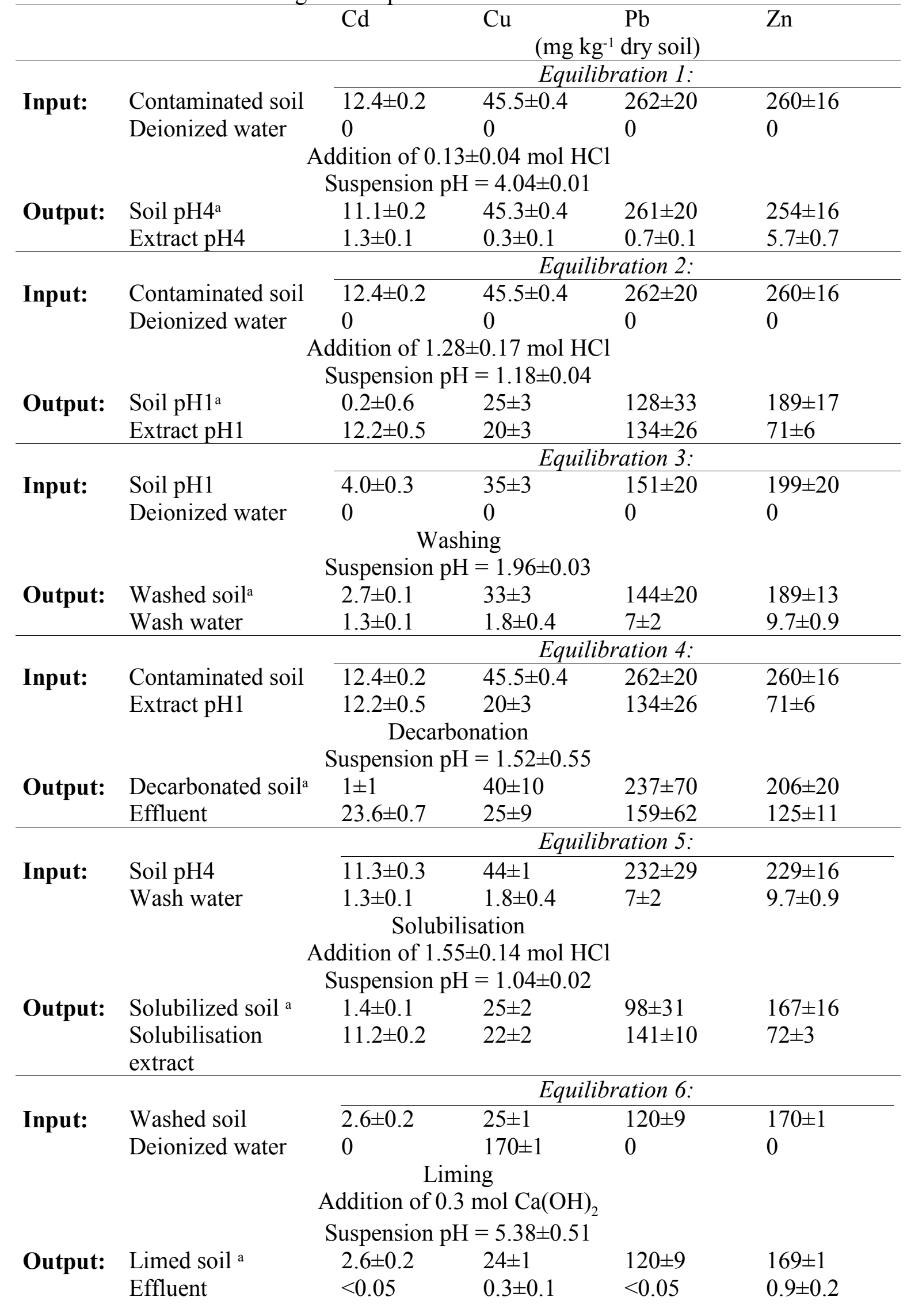

aValues calculated from the mass balance over the extraction 
TABLE III: Metal flow during batch equilibrations with the Tielrode soil.

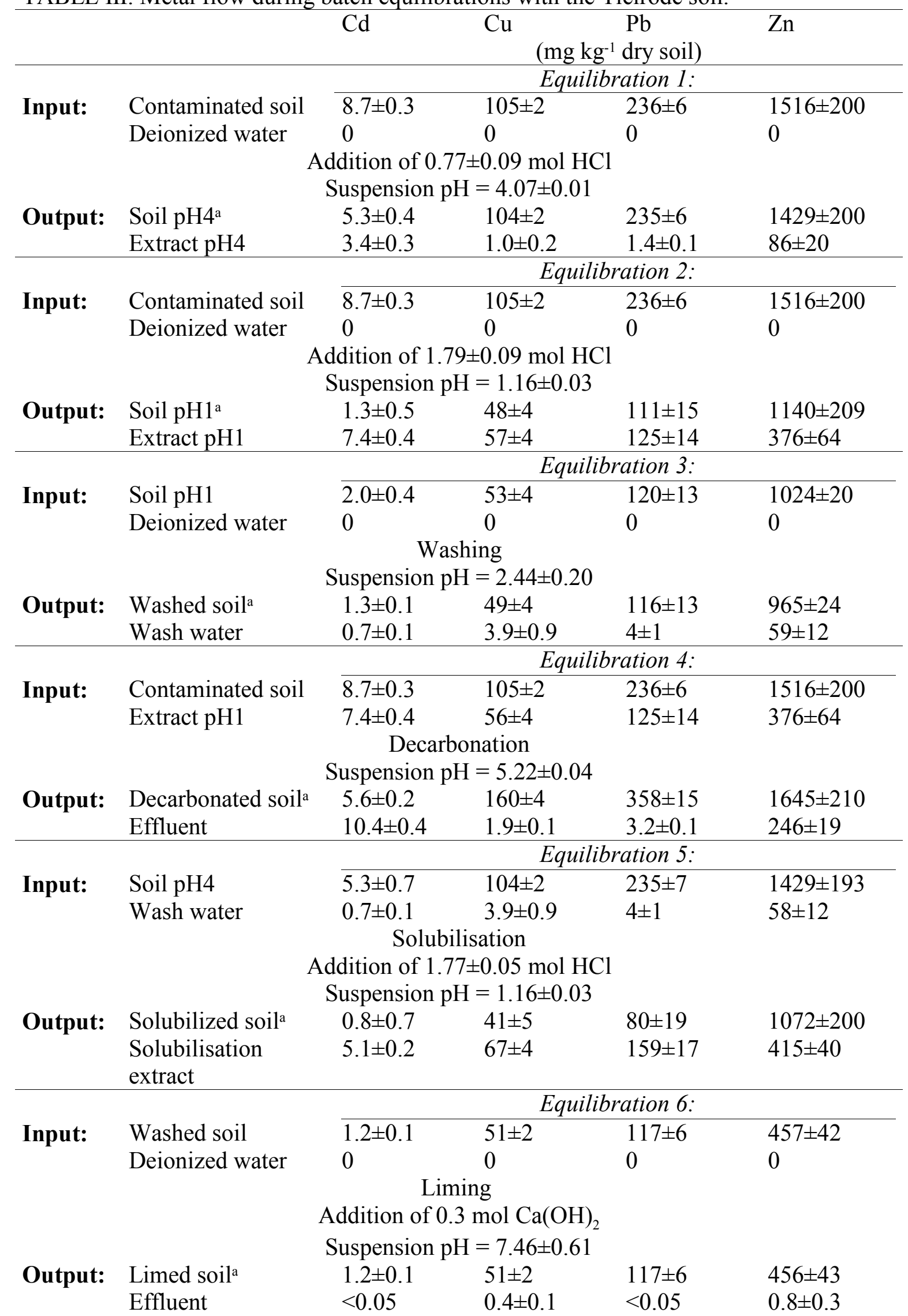

${ }^{a}$ Values calculated from the mass balance over the extraction 


\section{List of figures}

Fig. 1. Counter-current metal extraction scheme

Fig. 2. Acid titration curve for the soils from Tielrode and Kruibeke

Fig. 3. Solubilisation edges for cadmium, copper, lead, and zinc in the A) Kruibeke soil, and B) Tielrode soil

Fig. 4. Solid phase fractionation of A) cadmium, B) copper, C) lead, and D) zinc in the Kruibeke soil as affected by the following treatments: 1) native soil, 2) decarbonation, 3) solubilisation, 4) washing, and 5) liming

Fig. 5. Solid phase fractionation of A) cadmium, B) copper, C) lead, and D) zinc in the Tielrode soil as affected by the following treatments: 1) native soil, 2) decarbonation, 3) solubilisation, 4) washing, and 5) liming

Fig. 6. Counter-current metal flow in the Kruibeke soil (mg kg-1 dry soil)

Fig. 7. Counter-current metal flow in the Tielrode soil ( $\mathrm{mg} \mathrm{kg}^{-1}$ dry soil) 


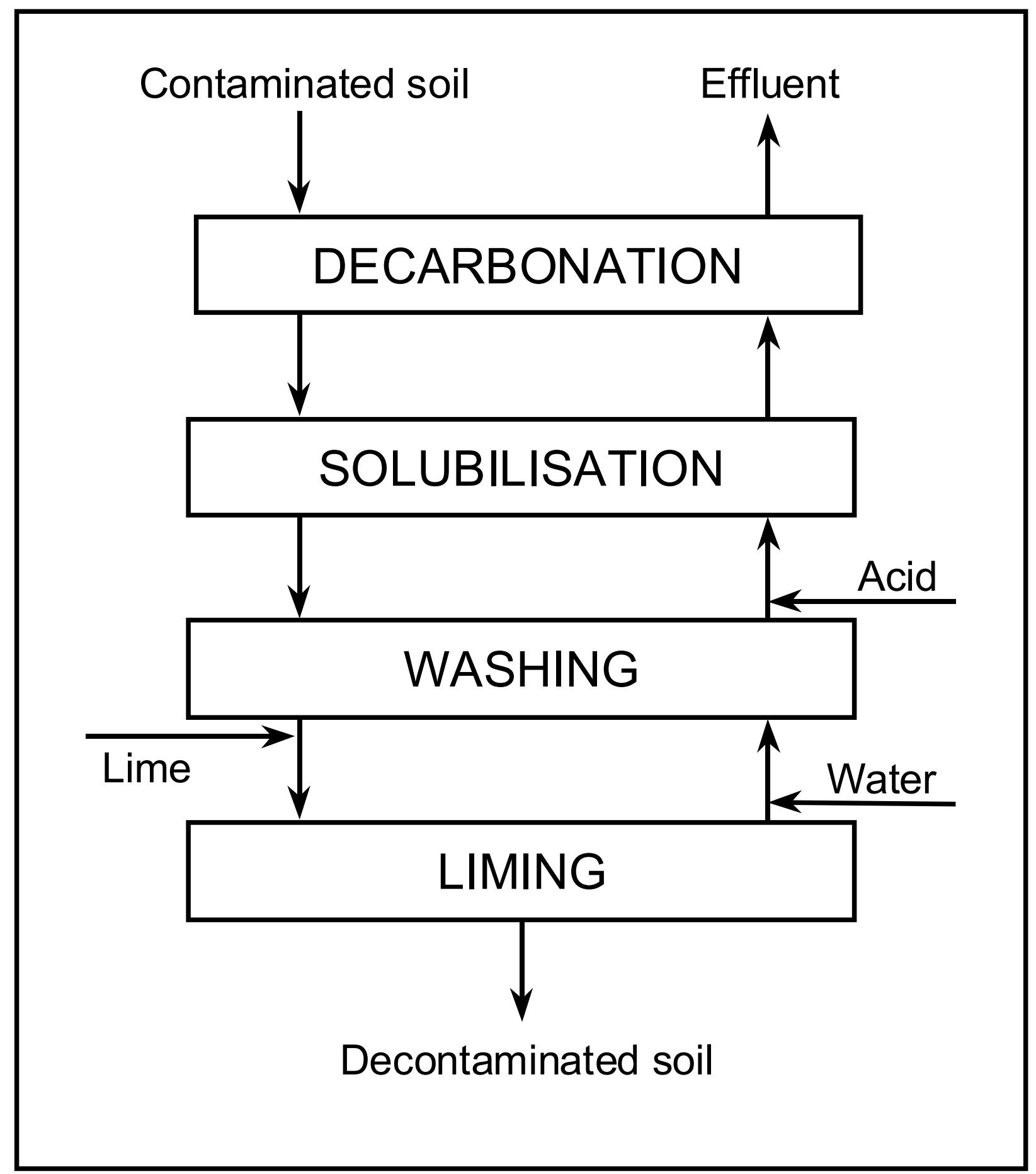


Figure 2

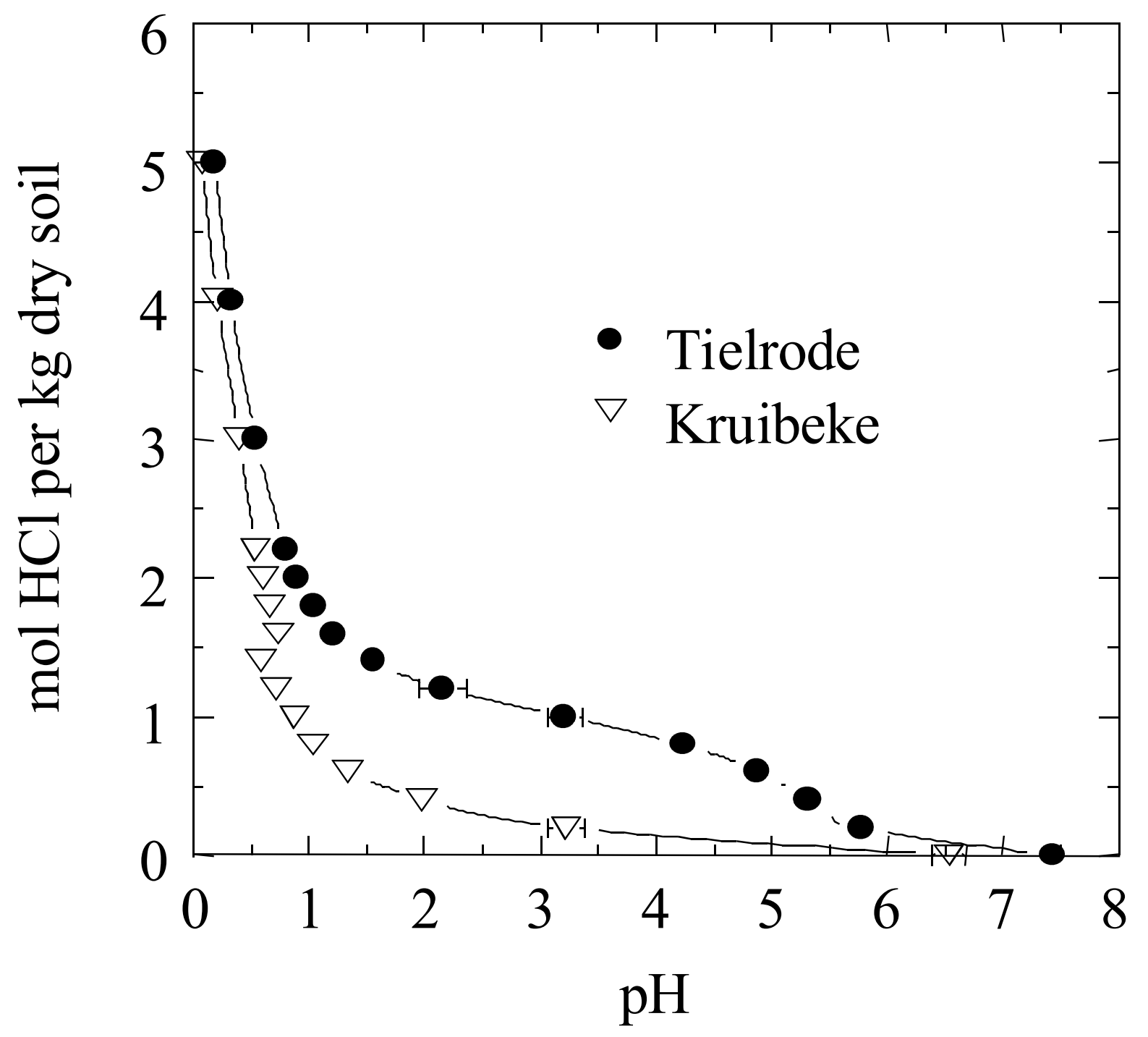


Figure 3
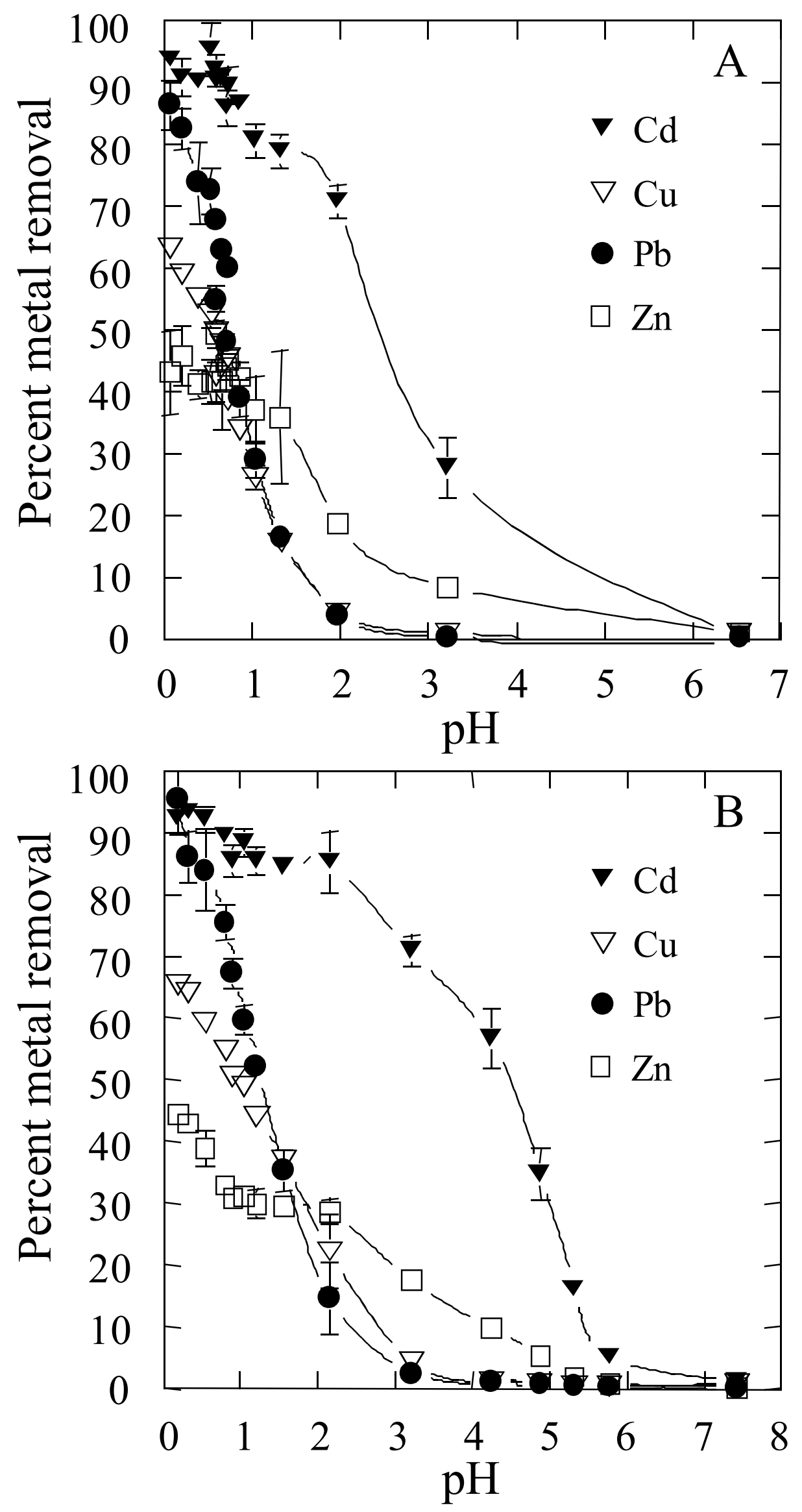
Figure 4
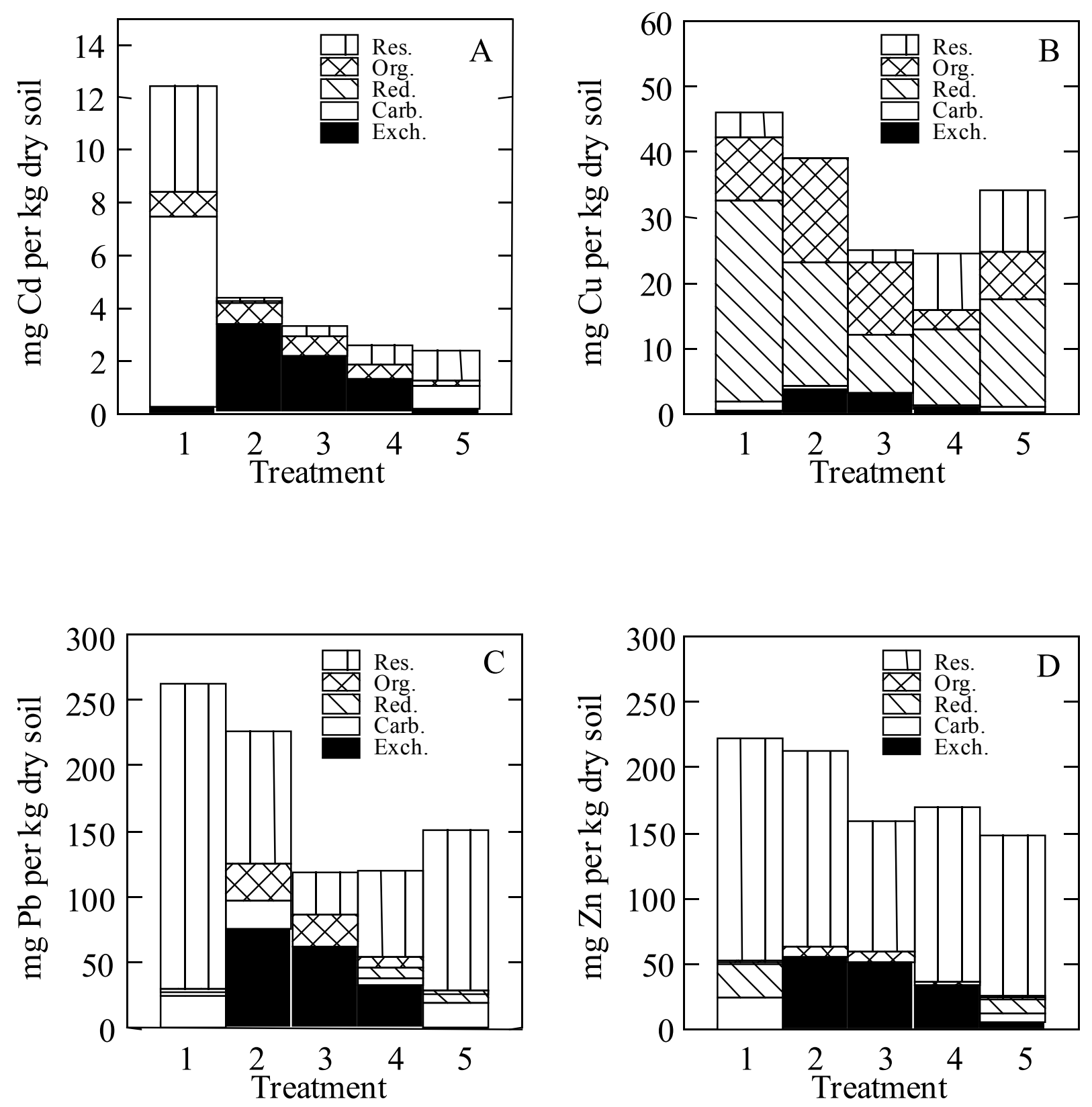
Figure 5
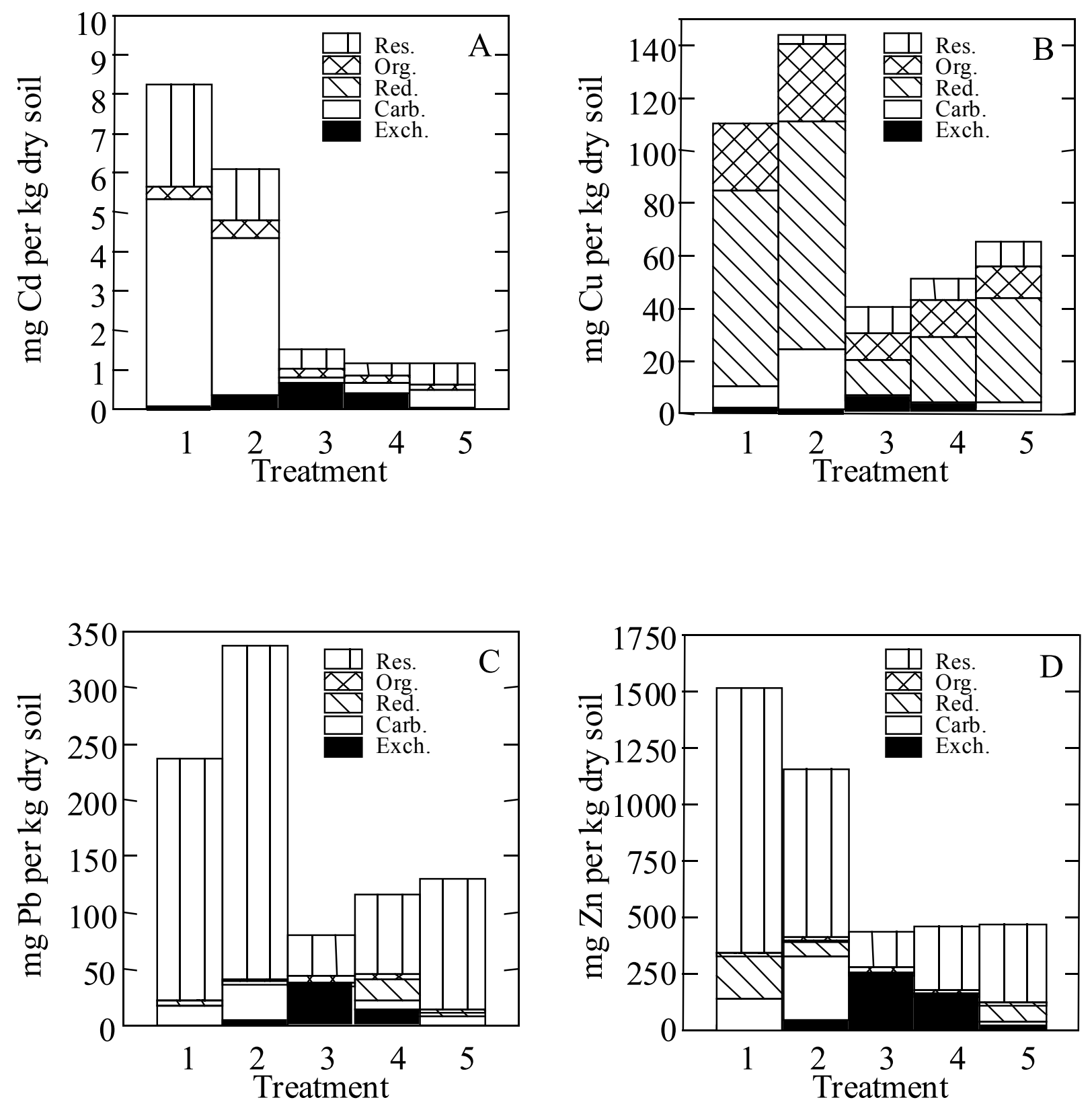
Figure 6

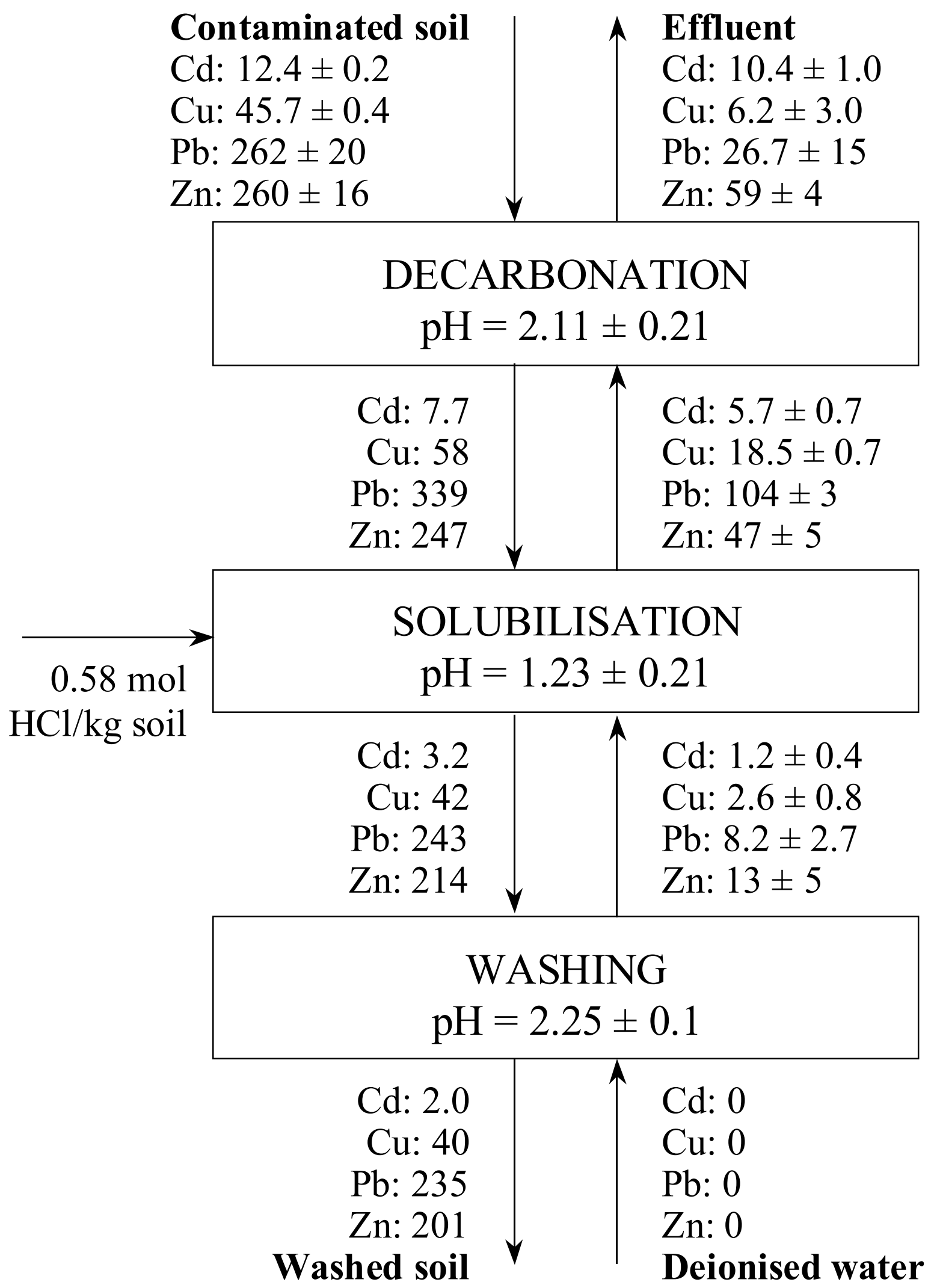


Figure 7

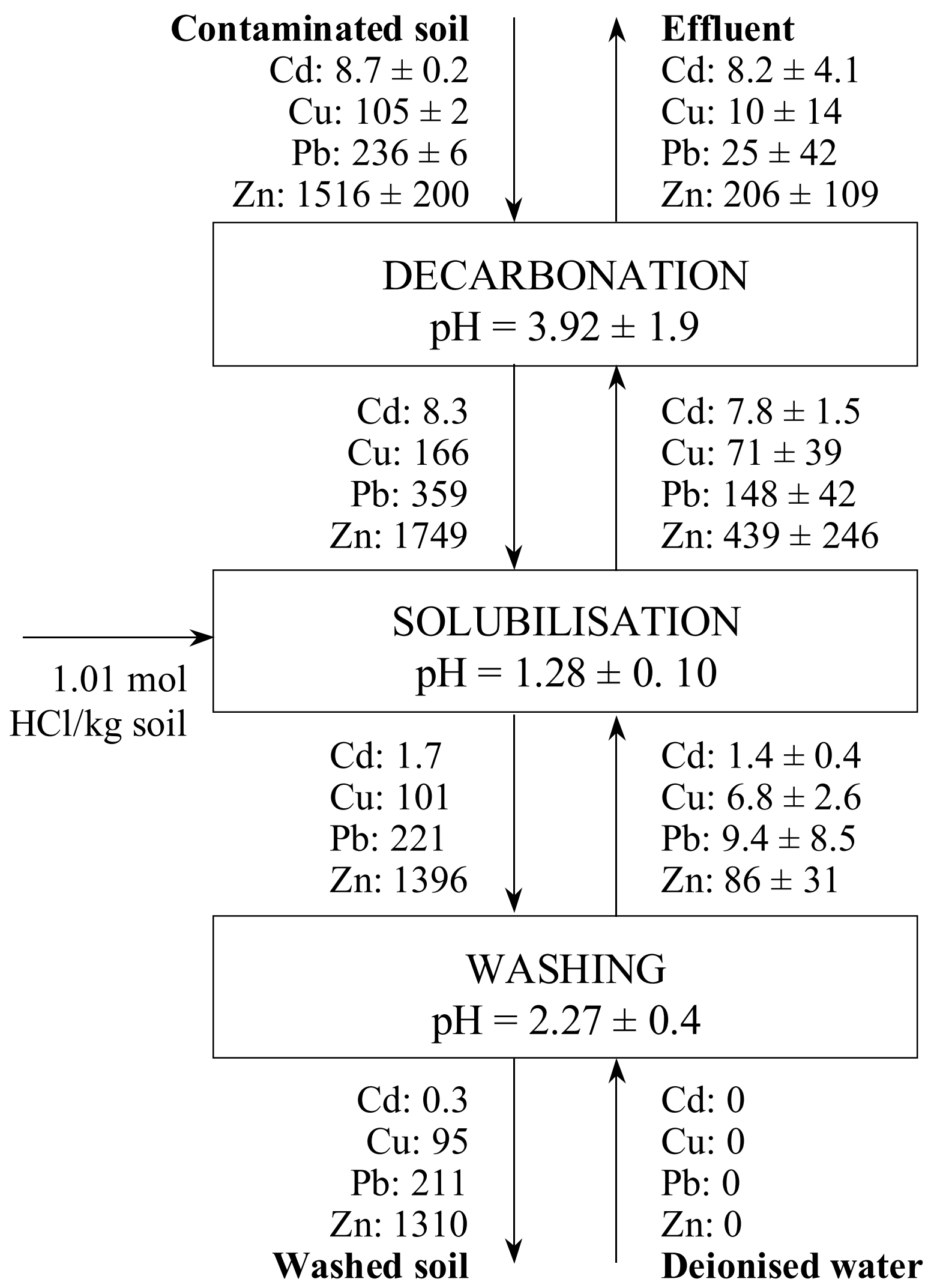

